\title{
System of Question Sentence in Tontemboan Language
}

\author{
Intama Jemy Polii ${ }^{*}$ \\ ${ }^{1}$ Manado State University, Indonesia \\ ${ }^{*}$ Correspondence: intamapolii@unima.ac.id
}

\section{ABSTRACT}

This study aims to describe the question system sentence of Tontemboan language based on its form, propositional function, and the meaning it refers to. This study used a qualitative method with a descriptive design. Based on the results of the research, the form of question sentences in the Tontemboan language can be classified into three types, namely (1) interrogative sentences marked by the use of interrogative words: sapa, sei, kawisya, ambisya, pira, kitu, and kensya, (2) question sentences marked by the use of interrogative intonation, and (3) interrogative sentences marked by the use of question particles re'en and wei. Based on the proposition, Indonesian language question sentences are categorized into: (1) WH-question questions, (2) yes-no questions, and (3) questions commonly called alternatives. The function of the Tontemboan language question sentence, according to the meaning, referred to varied dependence on the form of the question used, question word, intonation, and question particle
\end{abstract}

\section{ARTICLE HISTORY \\ Published March 27th 2021 \\ Check for updates \\ KEYWORDS \\ System; Question Sentence; Tontemboan Language. \\ ARTICLE LICENCE \\ (C) 2021 Universitas Hasanuddin \\ Under the license CC BY-SA

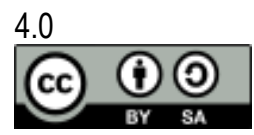

\section{Introduction}

Tontemboan language is one of the regional languages in North Sulawesi, precisely in the Minahasa area. As a language group, the Tontemboan language shows its own characteristics compared to other languages in the Minahasa area. This language has its own uniqueness in its syntactic system, such as question sentences. The Tontemboan regional language question sentence system is similar to Indonesian. Therefore, it is interesting to conduct a scientific study of the Tontemboan language question sentence system using syntactic tools.

The uniqueness of the question sentences in the Tontemboan language can be examined from its formulation process, propositions, and meanings, as in Indonesian. Rofi'uddin (1994: 27) who examined the Indonesian question sentence system suggests that Indonesian question sentences can be analyzed based on (1) question forms, (2) question propositions, and (3) question functions. According to Rofi'uddin, based on its shape, Indonesian sentences can be classified into three forms, namely: (1) using the word question, which is commonly called WH-question, (2) using question intonation, and (3) using question particles -kah and - lah.

A similar opinion was expressed by Alwi, et al. (1998: 357) that formally an interrogative sentence is marked by the presence of a question words like what, who, when, why, and how, ends with a question mark (?) In written language and in spoken language with an increased voice, especially if there is no question word. or the sound goes down. The form of the interrogative sentence is usually used to ask (1) yes or no answers and (2) information about something or someone from the interlocutor.

Based on temporary observations, in terms of syntactic form, Tontemboan language question sentences can be formed based on three ways (1) the using of question words: sapa, sei, kawisya, ambisya, pira, kitu and kensya, (2) the using of question intonation, and (3) the using of question particles re'en and wei. The form of the interrogative sentence in the Tontemboan language is similar to its form in Indonesian. In terms of propositions, the Tontemboan language question sentence requires various answers. Information / answers to the questions asked are inseparable from the form or type of questions asked or the propositions contained therein. Likewise, in terms of function, Tontemboan language question sentence has various functions depending on the information or answer requested. 
This study is aimed at expressing and describing Tontemboan language question sentence system based on its form, function based on propositions, and the meaning it referred to.

\section{Method}

This study used a qualitative method with a descriptive design. This research is intended to produce a comprehensive and representative description of Tontemboan language question sentence system. The research data was collected from 5 informants as native speakers of the Tontemboan language. The research took place in the area of the Tontemboan language speakers in the makala'ai dialect, namely in the village of Kanonang.

The researcher is the key instrument in capturing necessary data. The researcher also employed observation, interview and recording techniques. The data collected from these techniques are then validated or tested for their validity using triangulation techniques: method techniques, source techniques, and theoretical techniques. Data that has been tested for validity is then analyzed. Data analysis techniques used flow models (Miles \& Huberman, 1992). With this analysis model, data analysis is carried out during data collection and after data collection ends. Data analysis steps include: data reduction, data presentation, and conclusion / verification.

\section{Research Results}

Based on the results of the data analysis carried out, if it is viewed based on syntactic tools, the sentence form questions in the Tontemboan language can be classified into (a) having a question syntactic structure, namely using question words, (b) using question intonation, and (c) using question particles. These three forms of questioning are described below.

\subsection{Structured syntactic question (using question words)}

Question sentences in the Tontemboan language can be formed using a variety of interrogative words. The question words that make up the question sentence in the Tontemboan language are:

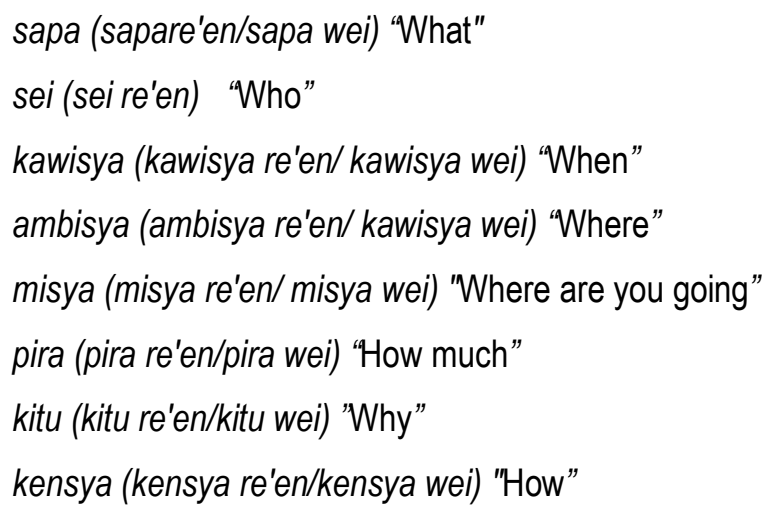

These question words are used for different purposes. The use of these words can be seen in the sentences below.
1) Sapa (what)
(1) Sapa nuitnu? (What are you carrying?)
(2) Sapa re'en enkanenta? (What are we going to eat?)
(3) Sapa wei nengkeina? (What is underneath?)

2) Sei (who)

(4) Sei si muwit towaku? ("Who brought cigarettes?)

(5) Sei re'en encumua aco? (Who said that to you?)

(6) Sei waya enme'ei kawengi? (Who were all of those who came over last night?) 
3) Kawisyah (When)

(7) Kawisya cita lumintud? (When do we start?)

(8) Kawisya re'en cita mange am Wenang? (When do we go to Manado?)

(9) Kawisya wei sila me'ei? (When did they come?)

4) Ambisya (Where)

(10) Winekarannu's ambition? ("Where did you put it?)

(11) Ambisya re'en embalenu? (Where is your house?)

(12) Ambisya wei en tawoyannu? (Where do you work?)

5) Misya (where / where)

(13) Misya ko kawengi (Where did you go last night?)

(14) Mass re'en ko anio '? (Where are you going now?)

(15) Mass wei ma 'surak oka? (Where do you hurry to?)

5) Pira (how many/how much?)

(16) Pira se me'ei tarepe '? (How many came earlier?)

17) Pira re? 'En emperlunu? (How much do you need?)

(18) Pira wei empinjamennu? (How much are you going to borrow?)

6) Kitu (why / why)

(19) Why is me'ei? (Why don't you come)?

(20) So re'en sia ca me'ei? (Why didn't he come)?

(21) Kitu wei, sa iaku ca mange? (Why if I don't go?)

7) Kensya (how / how)

(22) Kensya se toyaang nu? (How about your children?)

(23) Kensya re'en o sia lumetup? (How did he fall?)

(24) Kensya wei o memali? (How did that happen?)

The sentences above which use the interrogative words sapa, sei, kawisya, ambisya, wisya, pira, kitu, and kensya, it appears that the form of the Tontemboan language question sentence that uses the word question varies and is almost the same in number as in Indonesian. The question words that form the question sentence can occupy the initial position of the sentence. There are two patterns that appear, that each question word is followed by an affirmation of re'en and wei. Except for the question word sei is not commonly followed by wei.

The use of the interrogative word to form a question sentence in the Tontemboan language is not absolutely at the beginning of the sentence, but can also transpose in the middle or at the end of the sentence. The transposition of the interrogative words in the Tontemboan language question sentence can be seen in the sentences below.

(25) Ico sapa nengkei? (What do you bring?)

(26) Ico 'ei mengkei sapa? (What did you come with?) 
(27) Uma ia'na anu sei? (Whose garden is it?)

(28) Wale sei na'kna? (Whose house is it?)

(29) Sia mepo'ok o sei? (Who is he related to?)

(30) Ico kawisya kumaweng? (When were you married?)

31) Ico kumaweng kawisya? (When were you married?)

(32) Tumawoy ambisa ko anio'? (Where are you working now?)

(33) Wo'ndo ko mange ambisya? (Where are you going tomorrow)?

(34) Misya kawi'iy? (Where did he go to yesterday?)

(35) Icokawiliy misya? (Where did you go to yesterday?)

(36) Icopira seyaang? (How many children do you have?)

(37) Wo'ndo ico misya? (Where are you going to tomorrow?)

(38) Mak'lintu'dem kitu ko pe "me'ei? (It's already started, why haven't you arrived?)

(39) Ma 'buei kensya sumaru all matu'a? (Asking how to deal with parents)

Based on the sentence examples above, the syntactic behaviour of interrogative words to form question sentences in the Tontemboan language has the freedom to change places or positions. The shift in the position of the question word does not change the meaning or purpose of the question sentence.

\subsection{Using the intonation}

The question sentence in Tontemboan language is not only marked by the use of the word question. The question sentence can also be formed using only the intonation of the question at the end of the sentence. The form of the question sentence which is only marked by the use of intonation is as productive as used by Tontemboan speaking community of the makala'ai dialect with question sentences that use the interrogative word. The forms of the question sentence which are marked by the use of the intonation of the question are presented below.

(40) Joni cumawengem? (Is Joni married?)

(41) Si nenena ma'ame' tarepe'? (Did grandmother cry earlier?)

(42) Cita ro'nam tumekel (Can we sleep already?)

(43) Ca tumeles wi'ir ko engkeyen? (Didn't you bring rice you bought?)

(44) Aya'an tawoyen nu wo'ndo? (Do you have anything to do tomorrow?)

(45) Se toyaang na ma' scolah wayah? (Do All of his children go to school?)

(46) Cita memali mayak angkandoan? (Are we leaving on the day after tomorrow?)

(47) Memali sse ko'kok'nu wangker? (So, are your chicken sold?)

From the examples above, it shows that this sentence form is very productively used in public speaking events for various purposes. The sentence form of this question requires a short answer, because this type of question is a closed question type, which only requires an answer: true or not true, yes or no, agree or disagree. and want it or not. 


\subsection{Using the question particle re 'en and wei}

In addition to question sentences that use interrogative words and interrogative intonation, there are also question sentences formed by the use of the particles re 'en and wei in the Tontemboan language. The forms of this sentence can be seen in the following.

(48) Ca re'en mange ko? (You are leaving now, are not you?)

(49) Si poyo"na re'en en mate? (The dead grandson?)

(50) Si anak re'en matuanu en cumaweng? (Your oldest married son?)

(51) Ca me'ei wei sila? Didn't they come?

(52) Ro'na wei iaku kumiit? (Can I come along?)

(53) Ca wana ruit wei teles wilir? (Don't we have money to buy rice?)

Sentences (48-50) are characterized by the use of the question re'en particle and sentences (51-53) use the question wei particle. The form of the question sentence with the question particle is similar to the interrogative sentence which uses the intonation of the question. Both are closed question types that require a short answer. If associated with Indonesian, the particles re'en and wei are similar to the -kah particles. This type of question sentence only requires a short answer, namely yes or no.

\section{a. Question Function Based on Proposition}

Based on the proposition of Tontemboan language question sentence, there are three types of questions, as follows.

1. Questions that use a question word (wh-question)

(54) Who is nuitnu? (What are you carrying?)

(55) Sei the muwit towaku? (Anybody brought cigarettes?)

(56) Sei waya enme'ei kawengi? (Who were all who came last night?)

(57) Kawisya cita lumintud? (When do we start?)

(58) Ambisya winangkerannu (Where did you sell it ?!)

(59) Misya ko kawengi? (Where did you go last night?)

(60) Pira se me'ei tarepe'? (How many came earlier?)

(61) Kitu ko ca me'ei? (Why don't you come)?

(62) Kensya se toyaang nu? (How about your children?)

The propositions contained in the sentences above are all requests for information, according to the question words used. The proposition in sentence (54) the requested information is in the form of 'object'. Sentence proposition (55) asks for information relating to 'people', Proposition in sentence (56) 'number of people'. The proposition in sentence (57) asks for information about 'time'. The proposition in sentence (58) asks for information about the place (where). The proposition in sentence (59) calls for information about 'the place to go (where)'. The proposition in sentence (60) calls for information about the 'amount'. The proposition in sentence (61) asks for information on 'reasons / causes'. The proposition in sentence (62) calls for information on 'circumstances'.

\section{Yes/No question} sentences.

The proposition contained in this question requires a brief 'yes' or 'no' answer. This can be seen in the following

(63) Ico me'ei or ca? (Are you coming or not?)

(64) Si Markus mengkei pecol ato ca? (Did Mark bring a hoe or not?) 
(65) Masale' ko mange am Wenang ato ca? (Do you like to go to Manado or not?)

The proposition of these sentences requires short but "definite" answers. The answers that are asked of the question sentences are only yes or no.

\section{Alternative questions}

This question proposition is similar to the question of necessity, in that it requires a short answer. Only difference, if the question of necessity requires a short and definite answer, but the question is an alternative, depending on the alternatives offered. For example:

(66) Ensa ensaleknu, wuling atau rindang? (Which do you like black or red?)

(67) Ico masalek si litek ato si wangker? (Do you like the small or big one?)

(68) Ico muit kakanen ato ruit? (Do you bring food or money?)

(69) Uma entelesannu ato oto? (Are you going to buy a garden or a car?)

The question sentence proposition above asks for an answer in the form of a choice between the two mentioned. The sentence proposition (66) chooses between wuling (black) and rindang (red). Sentence (67) chooses between Jitek or Wangker. Sentence (68) chooses between kakanen (food) or ruit (money). Sentence (68) chooses between kakanen or ruit). Sentence (69) chooses uma or oto.

\section{b. Question Functions Based on the Meaning Referenced}

The question function uses the question word

Question sentences which are formed using the question word are very productive to be used, such as interrogative words: sapa, sei, kawisaya, misya. pira, kitu, and kensya. Each question word has a different meaning and function when seen from the answers requested. The following describes the function of the question which is formed by the question word.

1) Sapa (what / what)

(70) Sapa nuitnu? (What are you carrying?)

(71) Sapa re'en enkanenta? (What are we going to eat?)

(72) Sapa enmemali ambitu kawengi? (What happened there last night)

(73) Sapa en pa'papadla tarepe'? (What were they talking about earlier?)

Sentences (70-71) function to ask something 'goods or' things'. Sentence (92) asks 'events or incidents'. Sentence (73) has the function of asking 'the topic of conversation'.

2) Sei (who / who)

(74) Sei si muwit towaku '(Who brought cigarettes?)

(75) Sei re'en encumua aco? (Who said that to you?)

This sentence functions to ask a certain person or party, depending on the context that underlies the sentence of this question being asked. Even though the interrogative word sei transposes at the end of a sentence, its function does not change to ask people, either the owner or the actor as in the sentence (74-75).

3) Kawisyah (when / when)

The question sentence formed by the use of the word question kawisya (when) functions to ask the time: when it happened, when it was carried out, when an event or action took place. This can be seen in the following sentences. 
(76) Kawisya cita lumintud? (When do we start?)

(77) Kawisya re'en cita mange am Wenang? (When do we go to Manado?)

(78) Kawisya wei sila me'ei? (When do they come?)

Even if the interrogative word kawisya changes position either in the middle or at the end of the sentence, the function still asks for the time.

\section{4) Ambisyah (where / where)}

The question word ambisya functions to form question sentences that ask where the event took place, the location, or the destination.

(79) Ambisya winekarannu? ("Where did you put it?)

(80) Ambisa re'en embalenu? (Where is your house?)

(81) Ambisya wei en tawoyannu? (Where do you work?)

The question word ambisya in sentences (79-81) means asking for a place, such as 'where to put something', 'location or location' and 'the place to be addressed'. Even though the ambition changes positions in the middle and at the end, the function of the question sentence which is formed using this question word is still asking for a place.

5) Misya (where / where)

The interrogative sentence formed with the question word misya has the function of asking for a place, the same as the ambisya. However, the word question misya refers more to the intended place, as shown in the following sentences.

(82) Misya ko kawengi? (Where did you go last night?)

(83) Misya re'en ko anio'? (Where are you going now?)

(84) Misya wei ma 'surak oka? (Where do you hurry to?)

6) Pira (how much / how much?

The question word pira functions to ask the amount of money, people, things and animals.

(85) Pira se me'ei tarepe'? (How many came earlier?)

(86) Pira tou me'ei? (How many people came?)

(87) Pira seinu? (How many cows do you have?)

7) Kitu (why / why)

The question word kitu functions to ask the cause or reason for something happening or doing something. This is as shown in the following sentences.

(88) Kitu ko ca me'ei? (Why don't you come over?)

(89) Kitu re'en sia ca me'ei? (Why didn't he come over?)

(90) Kitu wei, sa iaku ca mange? (Why if I don't go?)

8) Kensya (how / how)

The interrogative formed sentence by the question word kensya has the function of asking about the situation, how something happened, how to do something, and the process of the event.

(91) Kensya se toyaang nu? (How about your children?) 
(92) Kensya re'en o sia lumetup? (How did he fall?)

(93) Kensya wei o memali? (How did that happen?)

Using the question intonation

The form of the question sentence which is only marked by the use of intonation is as productive as used by the Tontemboan speaking community of the makala'ai dialect with question sentences that use the interrogative word. The form of the question sentence which is marked by the use of the intonation of the question has various functions according to the purpose of this question being asked.

(94) Si Joni cumawengem? (Is Joni married)

(95) Si nenena ma'ame' tarepe'? (did the grandmother cry earlier?)

(96) Cita ro'nam tumekel? (Can we sleep?)

(97) Ca tumeles wi'ir ko engkeyen? (Didn't you bring the rice you brought?)

(98) Aya'an tawoyen nu wo'ndo? (Do you have anything to do tomorrow?)

The examples above show that the sentence form of this question requires a short answer, because this type of question is a closed question type, which only requires an answer: true or no, yes or no, agree or disagree. and want it or not.

\section{Using question particles re 'en and wei}

Question sentences that use re'en and wei particles in the Tontemboan language have various functions depending on the intent to be asked. The forms of this sentence can be seen in the following.

(99) Ca re'en mange ko? (Don't you go?)

(100) Si poyo'na re'en en mate? (The dead grandson?)

(101) Ca me'ei wei sila? (Didn't they come?)

The form of the question sentence with the question particles re'en and wei is similar to the interrogative sentence which uses the intonation of the question. When associated with Indonesian, the particles re'en and wei are similar to the -kah particles. This type of question sentence only requires a short answer, namely yes or no, agree or disagree.

\section{Discussion}

In terms of syntactic form, Tontemboan language question sentences can be formed in three ways, sure: (1) using question words: sapa, sei, kawisya, ambisya, pira, kitu and kensya, (2) using question intonation, and (3) using question particles re'en and wei. The sentence form for the Tontemboan language question has similarities with the form of the question sentence in Indonesian, such as the results of research by Rofi'uddin (1994: 27) which suggests that based on its form, Indonesian sentences can be classified into three forms, namely: (1) using question words, which is commonly called WH-question, (2) using question intonation, and (3) using question -kah and -lah particles. A similar opinion as expressed by Alwi, et al. (1998: 357) that the interrogative sentence is marked by the presence of question words like what, who, when, why, and how, ending with a question mark (?) In written language and in spoken language with an ascending voice.

Based on the question proposition, it varies according to the form of the question used, for example, by using the question word, the proposition asks objects, events, people, time of place, number, cause / reason, circumstances and the occurrence of an action or event. In addition, there are also question propositions that require short yes or no answers, or short but definite answers. There are also question propositions which are similar to questions of necessity or yes and no, namely alternative questions. The only difference is, if the question of necessity requires a short and definite answer, but the question in the form of an alternative offers a variety of options, depending on the choice put forward in the question sentence being asked. 
In terms of this proposition, the Tontemboan language question sentence is similar to Indonesian. Based on the proposition, Indonesian language question sentences are categorized into: (1) commonly called inevitability or yes-no questions, (2) questions commonly called alternatives, and (3) commonly called WH questions, (Rofi'uddin, 1993: 15-19).

The function of the Tontemboan language question sentence according to the meaning referred to is as diverse as Indonesian. A question sentence which is formed by using an interrogative word is like a question word: sapa, sei, kawisaya, misya. pira, kitu, and kensya have different functions. Each question word has a different meaning and function when seen from the answers requested. The question word sapa (what / what) functions to ask something / object, events or events, and the topic of conversation. The question word sei (who / who) has the function of asking a certain person or party, depending on the context that underlies the sentence of this question being asked. The question word kawisya (when) functions to ask the time when it happened, when it was carried out, when an event or action took place. The question word ambisya functions to form question sentences that ask where the event is taking place, the location, or the destination. The question word ambisya has the function of asking for places, such as' where to put something ', "location or location' and the place to be addressed. The question word misya (where) refers more to the place to be addressed. The question word pira (how much / how much) functions to ask the number money, people, objects, and animals. The question word kitu functions to ask the cause or reason for something happening or to do something. The question word kensyah (how / how) functions to ask about the condition, how something happened, how to do something, and the process of the event taking place.

The question sentence which is marked by the use of the intonation question requires a short answer, because this type of question is a closed question type, which only requires an answer: true or not, yes or no, agree or disagree. and want it or not.

Question sentences that use re'en and wei particles have various functions depending on the intent to be asked. The form of the question sentence with the question particles re'en and wei is similar to the interrogative sentence which uses the intonation of the question. If associated with Indonesian, the particles re'en and wei are similar to the -kah particles. This type of question sentence only requires a short answer, namely yes or no, agree or disagree.

\section{Conclusion}

The form of question sentences in the Tontemboan language can be classified into three types, namely (1) interrogative sentences marked by the use of interrogative words: sapa, sei, kawisya, ambisya, pira, kitu, and kensya, (2) interrogative sentences marked by the use of interrogative intonation, and (3) interrogative sentences marked by the use of question particles re'en and wei.

a. Based on the proposition, Indonesian language question sentences are categorized into: (1) WH question questions, (2) inevitability questions or yes-no questions, and (3) questions commonly called alternatives.

b. The function of the Tontemboan language question sentence according to the meaning referred to is as diverse as Indonesian. The question sentence is formed using the question word: sapa, sei, kawisaya, misya. pira, kitu, and kensya have different functions. The question sentence which is marked by the use of the intonation of the question requires a short answer, because this type of question is a closed question type, which only requires an answer: true or not, yes or no, agree or disagree, and whether you want it or not. Question sentences that use re'en and wei particles in the Tontemboan language have various functions depending on the intent to be asked. When associated with Indonesian, the particles re'en and wei are similar to the -kah particles. This type of question sentence only requires a short answer, namely yes or no, agree or disagree.

\section{References}

Abdulhay. (1983). Pengantar Sintaksis Bahasa Indonesia. Yogyakarta. Penerbit Lukman.

Alwi, H., et al. (2000). Tata Bahasa Indonesia Baku. Jakarta: Balai Pustaka.

Fraenkel, J.R. (1980). Helping Student Think and Value Strategies for Teaching the Soscial Student. New Jersey Prentice Hall.

Kristianti. (1997). Pertanyaan Guru dalam Pembelajaran di SD. Malang: UN Malang.

Lemlech, J.K. (1994). Currikulum and Instructional Methods for the Elementary and Middle School. (third edition). New York: Mcmillan College Publishing. 
Mahdin. (2004). Tindak Bertanya Guru dalam Pembelajaran Keterampilan Berbahasa. Malang: Universitas Negeri malang. Miles, M.B \& Huberman, A. M. (1992). Analisis Data Kualitatif buku sumber tentang metode-metode baru (T. R. Rohidi, ed.). Jakarta: Universitas Indonesia Press.

Moleong, L.J. (2000). Metodologi Penelitian Kualitatif. Bandung: Remaja Rosdakarya.

Rofi'uddin. (1993). Pertanyaan dalam bahasa Indonesia dan Pemakaiannya, Suatu Tinjauan Sosiolinguistik. Jurnal Penelitian IKIP Malang (2) Desember 1993.

Rofi'uddin. (1994). Sistem Kalimat Pertanyaan dalam Bahasa Indonesia. Disertasi tidak Diterbitkan. Malang PPs IKIP Malang. 